\title{
Effects of coffee (Coffea arabica) consumption on the femoral morphology and biomechanics in rats
}

\author{
Santos, MP. ${ }^{1}$, Pagani, JCM. ${ }^{1}$, Silva, TD. ${ }^{1}$, Garcia, JAD. ${ }^{1}$, \\ Romão, MOC. ${ }^{1}$, Fernandes, GJM. ${ }^{2}$ and Soares EA. ${ }^{2 *}$ \\ ${ }^{1}$ Faculty of Nursing and Medical Sciences, University José do Rosário Vellano - UNIFENAS, \\ Rod. MG 179, Km 0, Campus Universitário, CEP 37130-000, Alfenas, MG, Brazil \\ ${ }^{2}$ Laboratory of Anatomy, Federal University of Alfenas - UNIFAL, \\ Rua Gabriel Monteiro da Silva, 714, CEP 37130-000, Alfenas, MG, Brazil \\ *E-mail: eveanatomia@gmail.com
}

\begin{abstract}
Introduction: Coffee consumption has proved to be harmful to osseous tissue integrity, thus, diminishing bone resistance. Considering the great number of individuals consuming coffee daily, therefore, the present study aims to demonstrate the effects of coffee on the femoral morphology and biomechanics resistance in Wistar rats. Methods: Twenty male Wistar rats were chosen for the experiment, divided into two groups $(\mathrm{n}=10)$, as to know, CT (control) group, to which was offered water diet ad libitum; and, CF (coffee) group, to which was offered coffee as liquid diet. After 60 days, the animals had their blood analyzed for serum calcium level, they were euthanized and the right femurs were collected for histological procedure and the left ones were isolated for bone measures and mechanical test. Results: CF group animals do not present malnutrition or dehydration. Femur dimensions, trabecular bone width and cortical width analyses shown to be lower for CF group. Material and structural properties of the femurs of CF group animals demonstrate that this group presents weaker bones than those of CT group. Conclusion: The findings in the present study allow us to confirm that coffee consumption interferes negatively on the material and structural bone properties, diminishes trabecular and cortical bone density, and hence making bones more fragile and likely to fractures. So, due to the great number of individuals consuming coffee daily, it is important to reduce this consume on order to prevent bone trauma.
\end{abstract}

Keywords: coffee, bone, biomechanics, morphometry.

\section{Introduction}

Coffee is a popular drink with characteristic smell and taste and consumed all over the world (PINTO, 2002). On the strength of it, several studies concerning its security and health implications had been performed. Many investigations have demonstrated that caffeine, one of coffee's components, causes a number of pharmacological and cellular responses in a broad range of biological systems, such as central nervous system (CNS) and cardiac muscle stimulation, increase on diuresis, smooth muscle relaxation (SAKAMOTO, NISHIHIRA, FUJIE et al., 2001), vestibular changes (FELIPE, SIMÕES, GONCALVES et al., 2005), and may be related to enhanced fracture risk and osteoporosis development (COOPER, ATKINSON, WAHNER et al., 1992).

Coffee consumption is a Brazilian tradition, being the average data ranging $200-300 \mathrm{mg} /$ daily, where a regular Brazilian cup of coffee $(60 \mathrm{ml})$ contains $85-125 \mathrm{mg}$ of caffeine (HOGAN, HORNICK and BOUCHOUX, 2002; CAMARGO and TOLEDO, 1998). Coffee ingestion over $600 \mathrm{mg} /$ daily is considered excessive and can cause noxious effects to the organism (SADOCK and SADOCK, 2012).

Caffeine is considered to be the most psychoactive substance used worldwide (PARO, AIZENSTEIN, DELUCIA et al., 2008). About $80 \%$ of the world population consumes caffeine through food and beverage, such as coffee, tea, chocolate, soft drink, and through some medications taken as antagonistic agents of relaxing effect of some drugs (CAMARGO and TOLEDO, 1998). Caffeine (1,3,7 - Trimetilxantine) is a pharmacological active alkaloid belonging to the xanthine group (ALTIMARI, MELO, TRINDADE et al., 2005; BRUTON, 2012). After oral ingestion, it is quickly absorbed through GI tract and rapidly eliminated, with a half-life of 4-6 hours. It reaches its blood serum maximum level between 15 and 120 minutes after swallowing, spread out to all body tissues, and exhibits a strong pharmacological action on the CNS (SILVA, 2010; PARO, AIZENSTEIN, DELUCIA et al., 2008).

Coffee has also a diuretic action and functions as stimulating agent to the CNS (ALTIMARI, MELO, TRINDADE et al., 2005). Besides its effects on soft tissues, many studies have been demonstrating the negative effects of coffee drinking habit and of caffeine ingestion on resistant tissues as bony one (HALLSTRÖM, BYBERG, GLYNN et al., 2013; HALLSTRÖM, WOLK, GLYNN et al., 2006). Consuming caffeine through a daily coffee dose diminishes bone density, increases calcium excretion, easies the possibilities of occurring bone fractures (ANDRADE, SANT'ANA, MENDES JUNIOR et al., 2013) and osteoporosis development (SOUZA, 2010). Studies performed by Tsuang, Sun, Chen et al. (2006) with Wistar rats showed that caffeine accelerates osteoblastic apoptosis. LeblebiciogluBekcioglu, Paulson, Paulson et al. (1995) observed that 
fetuses of Wistar female rats submitted to caffeine presented abnormal and restrict osseous development.

As the precedent talks, coffee consumption has shown to be harmful to bone integrity, and consequently, can lessen osseous resistance. In this way, considering the great number of individuals consuming coffee daily, this study aims to evaluate experimentally the effects of coffee on bone mechanical resistance and Wistar rats' femur morphology.

\section{Material and Methods}

\subsection{Animal protocol}

This essay was approved by the Ethics Committee for Laboratory Animals (protocol $\mathrm{n}^{\circ}$ 01A/2008), according to the Brazilian Legislation on Experimental Animals (Federal Bill $n^{\circ}$ 6638/1979). This study also complied with the ethical principles outlined by the Brazilian College on Animal Experimentation (COBEA). For this experiment, 20 albino male rats (Rattus norvegicus - Wistar), 40-days old, were provided by the University Biotery, settled in the city of Alfenas, in the state of Minas Gerais, Brazil. The animals were divided into two groups $(\mathrm{n}=10)$ :

CT group (Control): all animals in this group were fed with Nuvilab CR-1 Autoclave ration for mice as solid diet and water ad libitum (at will) as liquid diet.

CF group (Coffee): all animals in this group received a coffee beverage as liquid diet. In order to standardize the amount of coffee to be offered, the daily consumption of five cups of $200 \mathrm{ml}$ for a $70 \mathrm{~kg}$ person and the ABIC (ASSOCIAÇÃO..., 2007) directions for coffee preparation were taken into account: that is, $100 \mathrm{~g}$ of coffee powder diluted in one liter of boiling water, as proposed by Araujo (2007) and Andrade, Sant'Ana, Mendes Junior et al. (2013). In the first seven days, the animals drank a preparation of $25 \mathrm{~g}$ of coffee powder diluted in one liter of boiling water, followed by 4 days of a preparation of $50 \mathrm{~g}$ of coffee powder diluted in one liter of boiling water in order to adapt the animals to full protocol. The coffee powder used in this study came from a ground roasted Coffea arabica registered trademark from the south of the state of Minas Gerais, roasted at $160{ }^{\circ} \mathrm{C}$ for about 13 minutes and graded as 45 ideal for consumption.

Experiment animals were placed into rodent cages, each one containing a $500 \mathrm{ml}$ bottle with water for CT group and coffee for CF group. Rats' weight was measured weekly and solid and liquid diet intake was verified each two days, as one performs liquid diet change daily along of the 60 days of experiment.

\subsection{Biological sample collecting and euthanasia protocol}

After 60 days, animals were anesthetized with a $1: 1$ ketamine (Francotar ${ }^{\circledR}$ ) and xylazine chloride (Virbaxyl 2\% ${ }^{\circledR}$ ) solution in the dose of $0.1 \mathrm{ml} / 100 \mathrm{~g}$ intra muscular (IM). Blood for laboratory serum calcium analysis was drawn by via retro-orbital. The serum concentrations of calcium were determined by chemiluminiscence and expressed in $\mathrm{mg} / \mathrm{dL}$ (SOARES, FAVARO, CAGNON et al., 2010). After euthanasia performed with an excessive anesthetic dosage, the rats' right femurs were removed for histological procedure. On the contrary, the rats' left femurs were removed, cleaned, measured (four dimensions), wrapped in $0.9 \%$ saline solution soaked up-gauze, and stored in a freezer $\left(-20{ }^{\circ} \mathrm{C}\right)$ until the day prior to mechanical test.

\subsection{Femur morphometry}

\subsubsection{Anatomical dimensions of the femur}

After removal of all soft tissue from the femurs, the following four measurements were obtained with a digital caliper and magnifying glass according to Lammers, German and Lightfoot et al. (1998): 1) femur length (measured from the most proximal point of the femoral head to the most distant end of the femur); 2) femoral diaphysis width (measured at the narrowest point of the mid-femur); 3 ) width of proximal femur (measured from the anterior point of the femoral head to the tip of the greater trochanter); 4) width of distal femur.

\subsubsection{Epiphyseal trabecular bone}

Femoral distal epiphysis ( $n=10$ per group) was used for this analysis. Six histological sections were prepared for each femur and two fields of each section were captured. The specimens were fixed in $10 \%$ buffered formalin solution for $72 \mathrm{~h}$ and decalcified in a formic acid, formalin and sodium citrate solution for 35 days. Next, the specimens were submitted to routine histological processing and embedded in paraffin. Longitudinal sections $(5 \mu \mathrm{m})$ were obtained and stained with hematoxylin eosin. The histological sections were examined by a Nikon $80 \mathrm{i}$ photomicroscope using a $20 \mathrm{x}$ objective. The images were captured with a Nikon DS-Ril camera for the analysis of trabecular bone area, area fraction and mean thickness using NISElements 3.0 Advanced Research software.

\subsubsection{Diaphyseal cortical bone}

The middle third of the femoral diaphysis $(n=10$ per group) was used for this analysis. Cross-sections $(5 \mu \mathrm{m})$ were obtained and stained with hematoxylin eosin. Twelve histological sections $(1$ section $=1$ field $)$ were prepared for each bone. The images were captured using a $4 \mathrm{x}$ objective and the cortical bone area (cross-section area) and mean cortical thickness were calculated.

\subsection{Mechanical test}

Animals' right femurs were removed and stored in a freezer $\left(-20{ }^{\circ} \mathrm{C}\right)$ until the day prior to mechanical test. For mechanical test, femurs ( $\mathrm{n}=10$ per group) were submitted to three-point bending test until complete fracture at a velocity of $3 \mathrm{~mm} / \mathrm{min}$. An MTS TestStar II set with a load cell of $100 \mathrm{Kgf}$ was used.

Each femur was tested in the anterior-posterior plane (concave-up position), with the anterior surface of the bone facing upwards. The load and displacement data were obtained directly from the MTS system and recorded with a computer coupled to the testing machine. These data were used for the acquisition and calculation of the structural properties: maximum load, displacement at maximum load, and extrinsic stiffness. The extrinsic stiffness was calculated as the slope of the most linear portion of the elastic region of the load-displacement curve (AKHTER, CULLEN, GONG et al., 2001; HUANG, LIN, CHANG et al., 2003). After testing of the specimens in three-point bending, the 
failure sites of all bone specimens were photographed, together with a measurement standard, by a high resolution digital camera at a standardized distance according to Huang, Lin, Chang et al. (2003).

The parameters of cross-sectional cortical bone area of the diaphysis were measured on the images using NIS-Elements 3.0 software (Advanced Research, USA). The cross-sectional moment of inertia (CSMI) at the point of failure was calculated by the method of Turner and Burr (1993):

$I=\frac{\pi}{64}\left[a b^{3}-(a-2 t)(b-2 t)^{3}\right]$

Where $I$ is the CSMI, $a$ is the width of the cross-sectional area in the medial-lateral direction, $b$ is the width of the cross-sectional area in the anterior-posterior direction and $t$ is the average cortical thickness (TURNER and BURR, 1993).

The material properties were obtained from the structural properties (AKHTER, CULLEN, GONG et al., 2001). The following material properties were evaluated: maximum stress, strain at maximum stress and elastic modulus. On the basis of the load-displacement data, these parameters were calculated using the following equations:

$\sigma=\frac{f o r c ̧ a \cdot L \cdot c}{4 I}$

$\varepsilon=\frac{12 \cdot c \cdot d}{L^{2}}$

$E=\frac{\text { rigidez } \cdot L^{3}}{48 I}$

Where $\sigma$ is the stress, $L$ is the distance between the two lower supports, $c$ is the maximum distance from pixels to the line that crosses the center of the mass, $E$ is the strain, $d$ is the displacement, and $E$ is the elastic modulus. The mechanical tests were carried out at the Laboratory of Mechanical Properties, Faculty of Mechanical Engineering, UNICAMP.

\subsection{Statistical analysis}

Final weight $(\mathrm{g})$, daily liquid intake $(\mathrm{ml})$, daily solid intake $(\mathrm{g})$, laboratory analysis, biomechanical analysis of the femurs, and morphological and morphometric comparison were statistically compared between the two groups by analysis of variance followed by Tukey's test, with the level of significance set at 1 and $5 \%$, respectively. Means with different letters were significantly different $(5 \%)$ from each other.

\section{Results}

All rats presented weight gain along the 60 days of the experiment. In the two groups, all animals took solid and liquid diet enough to provide them with hydration and energy necessary for maintaining daily body activities. For CT group animals, solid intake was superior to that for CF group. When comparing liquid intake, there were no significant differences between the groups (Table 1).

Results referring to total serum calcium and ionic calcium levels showed significant differences between the two groups (Table 1). CF rats presented lower total calcium and ionic calcium serum levels when compared to those of CT group (Table 1).
Femur's dimensions analyses revealed that CT animals presented higher femur length when compared to CF group ones (Table 2). Values obtained from the measurement of width of proximal femur, femoral diaphysis width and width of distal femur of CF group animals were inferior to those taken from CT group rats (Table 2).

CF group rats presented the least trabecular area dimension, trabecular width, cortical area and cortical width when compared to CT group animals (Table 2; Figures 1 and 2). Morphometric parameters for spongy bone of femur distal epiphysis in CF group animals were about $23 \%$ lower than those in CT group ones. Cortical width and cortical area of femur diaphysis measures for CF group animals were respectively $35.2 \%$ and $15.8 \%$ lower than those taken from CT group rats (Table 2; Figures 1 and 2).

Results obtained from femur mechanical test showed that it was necessary a lower maximum load for complete bone fracture in CF group animals. Relating load-displacement, there were no significant differences between the two groups' rats (Table 3 ). Stiffness evaluation demonstrated that there were statistical significant differences between CF and CT groups, with CF group animals presenting lower values (Table 3). Maximum stress values in CF group animals were lower than those obtained analyzing CT group rats (Table 3). The femur elastic modulus for CT group animals was significantly higher. Strain values taken from femurs of CT group rats were higher than those from CF group

Table 1. Weekly weight gain $(\Delta \mathrm{wg})$, daily fluid intake, daily solid intake and total calcium and ionic calcium concentrations for animals of groups CT and CF.

\begin{tabular}{lcc}
\hline \multicolumn{1}{c}{ Variable } & CT & CF \\
\hline $\mathrm{N}$ & 10 & 10 \\
$\Delta \mathrm{wg}$ & $287 \pm 2.1^{\mathrm{a}}$ & $286 \pm 1.0^{\mathrm{a}}$ \\
Solid intake $(\mathrm{g})$ & $55 \pm 1.0^{\mathrm{a}}$ & $49 \pm 0.6^{\mathrm{b}}$ \\
Fluid intake $(\mathrm{ml})$ & $41 \pm 0.7^{\mathrm{a}}$ & $41 \pm 0.3^{\mathrm{a}}$ \\
Total calcium $(\mathrm{mEq} / \mathrm{l})$ & $18 \pm 1.5^{\mathrm{a}}$ & $12 \pm 1.3^{\mathrm{b}}$ \\
Ionic calcium $(\mathrm{mmol} / \mathrm{l})$ & $1.2 \pm 0.06^{\mathrm{a}}$ & $1.3 \pm 0.06^{\mathrm{b}}$ \\
\hline
\end{tabular}

Two means followed by the same letter did not differ from one another ( $>0.05$, Tukey's test). Results are reported as the mean \pm standard deviation.

Table 2. Morphometric parameters obtained for animals of groups CT and CF.

\begin{tabular}{lcc}
\hline \multicolumn{1}{c}{ Measure } & CT & CF \\
\hline FL $(\mathrm{mm})$ & $23.0 \pm 0.4^{\mathrm{a}}$ & $21 \pm 0.5^{\mathrm{b}}$ \\
PW $(\mathrm{mm})$ & $9.0 \pm 0.10^{\mathrm{a}}$ & $7.5 \pm 0.07^{\mathrm{b}}$ \\
Wdia $(\mathrm{mm})$ & $6.0 \pm 0.2^{\mathrm{a}}$ & $4.8 \pm 0.1^{\mathrm{b}}$ \\
DW $(\mathrm{mm})$ & $7.8 \pm 0.16^{\mathrm{a}}$ & $5.7 \pm 0.07^{\mathrm{b}}$ \\
TA $\left(\mathrm{mm}^{2}\right)$ & $13.5 \pm 0.2^{\mathrm{a}}$ & $10.4 \pm 0.1^{\mathrm{b}}$ \\
TT $(\mathrm{mm})$ & $1.1 \pm 0.02^{\mathrm{a}}$ & $0.85 \pm 0.05^{\mathrm{b}}$ \\
CA $\left(\mathrm{mm}^{2}\right)$ & $22.2 \pm 0.1^{\mathrm{a}}$ & $18.7 \pm 0.13^{\mathrm{b}}$ \\
CT $(\mathrm{mm})$ & $3.7 \pm 0.02^{\mathrm{a}}$ & $2.4 \pm 0.01^{\mathrm{b}}$ \\
\hline
\end{tabular}

FL: femur length; PW: proximal femur width: Wdia: diaphyseal femur width; DW: distal femur width; TA: trabecular area; TT: trabecular thickness; CA: cortical area; CT: cortical thickness. Results are reported as the mean \pm standard deviation. Two means followed by the same letter did not differ from one another ( $\mathrm{p}>0.05$, Tukey test). 

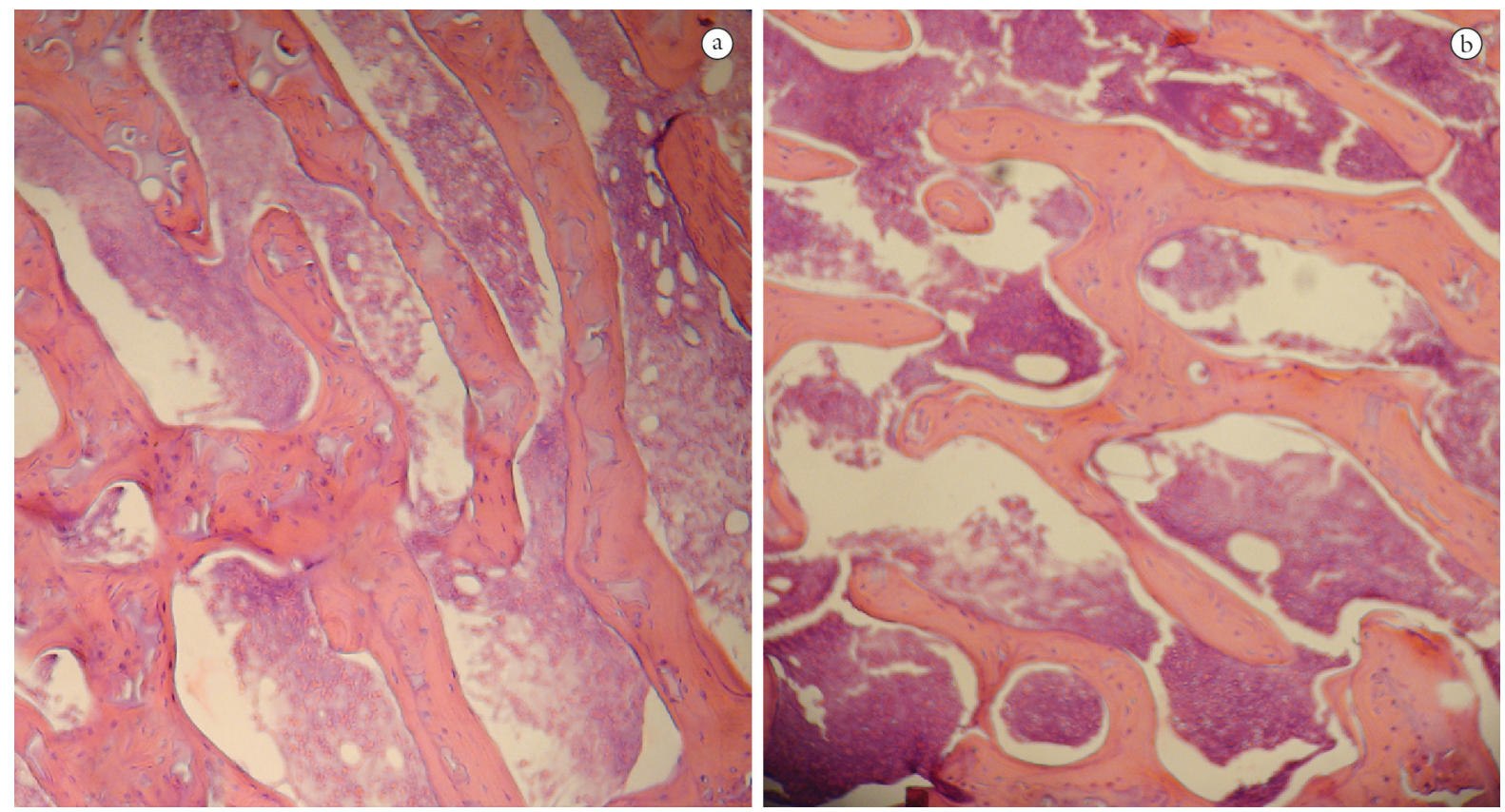

Figure 1. Photomicrographs of cross-sections of the femur showing spongy bone in the distal femoral epiphysis of rats of groups CT (a) and CF (b) (hematoxylin eosin staining). The reduced trabecular thickness and smaller trabecular area in the femur of animals of group CF are clearly visible (20x objective).
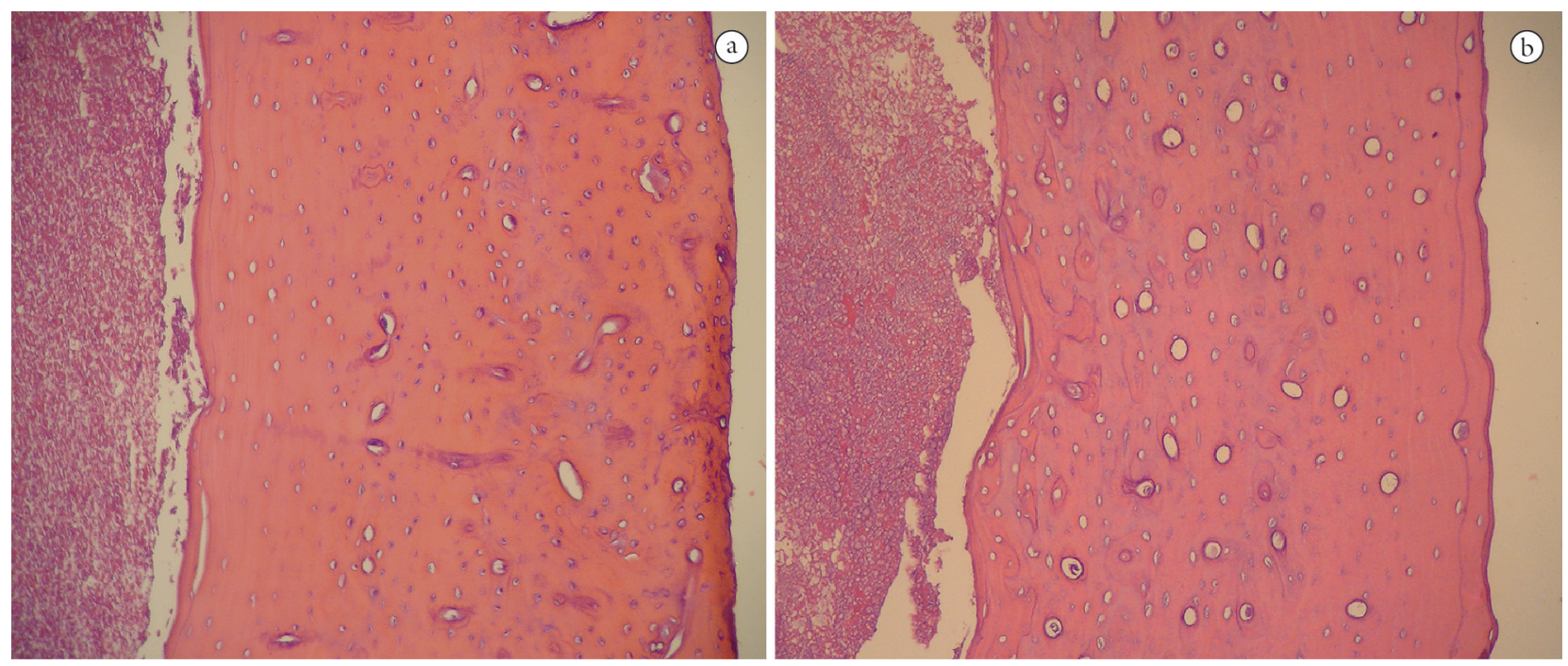

Figure 2. Photomicrographs of cross-sections of the femoral diaphysis of rats of groups CT (a) and CF (b) (hematoxylin eosin staining). The reduced cortical thickness in the femur of animals of group CF is clearly visible (4x objective).

animals. All material properties analyzed in CF group rats' femurs were inferior when compared to those in CT groups animals' ones (Table 3).

\section{Discussion}

The relationship between coffee consumption and osseous tissue alterations has been discussed in several different studies (COOPER, ATKINSON, WAHNER et al., 1992; ANDRADE, SANT'ANA, MENDES JUNIOR et al., 2013; HALLSTRÖM, BYBERG, GLYNN et al., 2013); however, literature still lacks data correlating coffee effects upon bone biomechanical properties.
The present study demonstrated that coffee consumption indeed altered biomechanical properties and morphometric features of rats' femurs; however, the controlled solid and liquid diet to which experiment animals were put on do not provoke malnutrition or dehydration. Researches involving drugs or specific substances use need to be considered carefully concerning experiment animals' nutritional status because variations in solid and liquid diet intake can lead to changes in animals' biological responses (MARKS ande POPOFF, 1988). According to Svendsen and Hau (1984), to keep an adequate nutritional status for rats and avoid malnutrition and dehydration one should provide them 
Table 3. Structural and material properties of femurs of animals of groups CT and CF.

\begin{tabular}{lcc}
\hline Mechanical properties & CT & CF \\
\hline Structural properties & & \\
Maximum load (N) & $169.0 \pm 35^{\mathrm{a}}$ & $102.3 \pm 19^{\mathrm{b}}$ \\
Displacement (mm) & $0.68 \pm 0.3^{\mathrm{a}}$ & $0.60 \pm 0.5^{\mathrm{a}}$ \\
Stiffness (N/mm) & $110.0 \pm 18^{\mathrm{a}}$ & $45.0 \pm 8.5^{\mathrm{b}}$ \\
Material properties & & \\
Maximum stress (MPa) & $25.0 \pm 7.0^{\mathrm{a}}$ & $16.2 \pm 2.1^{\mathrm{b}}$ \\
Strain (mm/mm) & $2.2 \pm 0.3^{\mathrm{a}}$ & $1.6 \pm 0.1^{\mathrm{b}}$ \\
Elastic modulus (MPa) & $90.5 \pm 50^{\mathrm{a}}$ & $49.0 \pm 9.7^{\mathrm{b}}$ \\
\hline
\end{tabular}

Results are reported as the mean \pm standard deviation. Two means followed by the same letter did not differ from one another ( $p>0.05$, Tukey test).

with a mean daily intake over $25 \mathrm{~g}$ of ration and $15 \mathrm{ml}$ of water. Our results showed that all animals gain weight along the experiment; thus, solid and liquid diet intake remained within standard patterns. Considering these traits, femurs' biomechanical and morphometric parameters were lesser in CF group animals in terms of coffee consumption.

Effects of coffee consumption on bone metabolism are still controversial, although many studies have suggested that caffeine and/or coffee are related to a significant increase of fracture risk, osteoporosis, bone mineral density reduction (HALLSTRÖM, BYBERG, GLYNN et al., 2013; HALLSTRÖM, WOLK, GLYNN et al., 2006), lessening of bone volume around implant and delaying in bone reparation process (ANDRADE, SANT'ANA, MENDES JUNIOR et al., 2013).

Lacerda, Matuoka, Macedo et al. (2010) studied the effects of coffee consumption on rats' bone metabolism and concluded that coffee causes severe adverse effects in calcium metabolism, bone mineral density diminishing, and bone volume reduction. Our study displayed that serum ionic calcium and total calcium levels in CF group animals were lower than those observed in CT group rats, confirming the relationship between coffee consumption and reduction of calcium levels.

Bedani and Rossi (2005) point out that about 99\% of body calcium content is found in the skeleton, giving to it stiffness and figuring out as a source readily available for maintenance of serum calcium normal concentration. The reduction of serum calcium level as well as unbalance between bone calcium apprehension and its deposition on the bones are risk factors for osteoporosis. Bone mineral density diminishing observed in osteoporosis is the riskiest factor for bone fracture (RODRÍGUEZ-MARTÍNEZ and GARCÍA-COHEN, 2002). A study carried out by Hallström, Wolk, Glynn et al. (2006) showed that a daily dose of $330 \mathrm{mg}$ of caffeine, equal to four cups of coffee $(600$ $\mathrm{ml}$ ), or more, can be related a moderately increased risk for osteoporotic fracture, particularly in women with a calcium low intake.

According to Leite, Figueiredo, Guia et al. (2008), trabecular bone volume reduction is seen in X-ray exams of osteoporosis patients. Data obtained from that study demonstrated that coffee consumption reduced bone trabecular width and area, and also as for cortical bone, being these important factors to propitiate bone fractures.

In relating to bone growth, a study performed by Rodrigues (2012) evaluated the effects of caffeine and coffee consumption levels during growth period on femur and tibia length and ascertained that groups of rats treated with coffee solution with a higher caffeine concentration presented the least femur and tibia length. In the present study it was also possible to detect lower femur dimensions in CF group animals when compared to those of CT group. As one used 40-days old animals for this experiment, coffee consumption in fact influenced femur growth for the sample was composed of young rats.

Bone calcium level change is associated to diminishing of both yield stress and elastic modulus (BURSTEIN, ZIKA, HEIPLE et al., 1975; SOARES, NAKAGASHI, GARCIA et al., 2012). Our data confirm these studies as to show that CF group animals had a lower calcium level and higher compromising in femur mechanical properties. Mechanical tests allow precise knowledge concerning bone material and structural properties (SOARES, NAKAGASHI, GARCIA et al., 2012). Material properties are related to tissue composition (cells, organic and inorganic parts) while structural properties are related to the organ as a whole (volume, architecture, size and distribution) (FERRETTI, CAPOZZA, MONDELO et al., 1993). Thus, relationship between coffee consumption and osseous tissue alterations, as described previously, is evident in our results.

In our study, femur mechanical analysis verified that structural (maximum load, displacement and stiffness) and material (maximum stress, strain, and elastic modulus) properties were higher in CF group and lower in CT group animals. This finding is indicative that femurs in CF group can present themselves with damage in organization and in collagenous content, and less mineral content, making bones less resistant and more likely to be fractured. In this way, coffee consumption increased bone fragility.

\section{Conclusion}

The findings in our study clearly outstand that coffee consumption interferes negatively on bone material and structural properties, and lessens femur trabecular and cortical bone volume, making bones weaker and fracture likely. Therefore, due to the great number of individuals consuming coffee daily, the reduction of coffee intake is an important factor in order to prevent bone traumas.

\section{References}

AKHTER, MP., CULLEN, DM., GONG, G. and RECKER, RR. Bone biomechanical properties in prostaglandin EP1 and EP2 knockout mice. Bone, 2001, vol. 29, n. 2, p. 121-125. http:// dx.doi.org/10.1016/S8756-3282(01)00486-0

ALTIMARI, L., MELO, J., TRINDADE, M., TIRAPEGUI, J. and CYRINO, E. Efeito ergogênico da cafeína na performance em exercícios de média e longa duração. Revista Portuguesa de Ciências do Desporto, 2005, vol. 5, n. 1, p. 87-101.

ANDRADE, AR., SANT'ANA, DCM., MENDES JUNIOR, JA., MOREIRA, M., PIRES, GC., SANTOS, MP., FERNANDES, GJM., NAKAGAKI, WR., GARCIA, JAD., LIMA, CC. and SOARES, EA. Effects of cigarette smoke inhalation and coffee consumption on bone formation and osseous integration of hydroxyapatite implant. Brazilian Journal of Biology, 2013, vol. 73, n. 1, p. 173-177. PMid:23644799. http://dx.doi.org/10.1590/ S1519-69842013000100018

ARAUJO, FA. Café (Coffea arabica L.) submetido à diferente torrefação: caracterização química e avaliação da atividade antioxidante e sensorial. São Paulo: Universidade de São Paulo, 2007. 157 p. [Tese de Doutorado em Nutrição Experimental]. 
Associação Brasileira da Indústria do Café - ABIC. Tipo de preparo de café. 2007. Rio de Janeiro. Available from: <http://www.abic. com.br>.

BEDANI, R. and ROSSI, EA. O consumo de cálcio e a osteoporose. Semina: Ciências Biológicas e da Saúde, 2005, vol. 26, n. 1, p. 3-14. http://dx.doi.org/10.5433/1679-0367.2005v26nlp3

BRUTON, LL. As bases farmacológicas da terapêutica de Goodman \& Gilman. 12. ed. Porto Alegre: AMGH, 2012.

BURSTEIN, AH., ZIKA, JM., HEIPLE, KG. and KLEIN, L. Contribution of collagen and mineral to the elastic-plastic properties of bone. Journal of Bone and Joint Surgery, 1975, vol. 57, n. 7, p. 956-961. PMid:1184645.

CAMARGO, MCR. and TOLEDO, MCF. Teor de cafeína em cafés brasileiros. Ciência e Tecnologia de Alimentos, 1998, vol. 18, n. 4 , p. 421-424. http://dx.doi.org/10.1590/S010120611998000400012

COOPER, C., ATKINSON, EJ., WAHNER, HW., O'FALLON, WM., RIGGS, BL., JUDD, HL. and MELTON, LJ. Is caffeine consumption a risk factor for osteoporosis? Journal of Bone and Mineral Research, 1992, vol. 7, n. 4, p. 465-471. PMid:1609631. http://dx.doi.org/10.1002/jbmr.5650070415

FELIPE, L., SIMÕES, LC., GONCALVES, DU. and MANCINI, PC. Avaliação do efeito da cafeína no teste vestibular. Revista Brasileira de Otorrinolaringologia, 2005, vol. 71, n. 6, p. 758-762. http://dx.doi.org/10.1590/S0034-72992005000600012

FERRETTI, JL., CAPOZZA, RF., MONDELO, N. and ZANCHETTA, JR. Interrelationships between densitometric, geometric and mechanical properties of rat femora: inferences concerning mechanical regulation of bone modeling. Journal of Bone and Mineral Research, 1993, vol. 8, n. 11, p. 1389-1396. PMid:8266830.

HALLSTRÖM, H., BYBERG, L., GLYNN, A., LEMMING, EW., WOLK, A. and MICHAËLSSON, K. Long-term coffee consumption in relation to fracture risk and bone mineral density in women. American Journal of Epidemiology, 2013, vol. 78, n. 6, p. 898-909. PMid:23880351. http://dx.doi.org/10.1093/aje/kwt062

HALLSTRÖM, H., WOLK, A., GLYNN, A. and MICHAËLSSON, $\mathrm{K}$. Coffee, tea and caffeine consumption in relation to osteoporotic fracture risk in a cohort of Swedish women. Osteoporosis International, 2006, vol. 17, n. 7, p. 1055-1064. PMid:16758142. http://dx.doi.org/10.1007/s00198-006-0109-y

HOGAN, EH., HORNICK, BA. and BOUCHOUX, A. Focus on communications: communicating the message: clarifying the controversies about caffeine. Nutrition Today, 2002, vol. 37, n. 1, p. 28-35. PMid:1 1984429. http://dx.doi. org/10.1097/00017285-200201000-00010

HUANG, TH., LIN, SC., CHANG, FL., HSIEH, SS., LIU, SH. and YANG, RS. Effects of different exercise modes on mineralization, structure, and biomechanical properties of growing bone. Journal of Applied Physiology, 2003, vol. 95, n. 1, p. 300-307. PMid:12611764.

LACERDA, SA., MATUOKA, RI., MACEDO, RM., PETENUSCI, SO., CAMPOS, AA. and BRENTEGANI, LG. Bone quality associated with daily intake of coffee: a biochemical, radiographic and histometric study. Brazilian Dental Journal, 2010, vol. 21, n. 3, p. 199-204. PMid:21203700. http://dx.doi.org/10.1590/ S0103-64402010000300004

LAMMERS, AR., GERMAN, RZ. and LIGHTFOOT, PS. The impact of muscular dystrophy on limb bone growth and scaling in mice. Acta Anatomica, 1998, vol. 162, n. 4, p. 199-208. http:// dx.doi.org/10.1159/000046435

LEBLEBICIOGLU-BEKCIOGLU, B., PAULSON, RB., PAULSON, JO., SUCHESTON, ME., SHANFELD, J. and BRADWAY, SD. Effects of caffeine and nicotine administration on growth and ossification of the ICR mouse fetus. Journal of Craniofacial Genetics and Developmental Biology, 1995, vol. 15, n. 3, p. 146-156. PMid:8642054.
LEITE, AF., FIGUEIREDO, PTS., GUIA, CM., MELO, NS. and PAULA, AP. Radiografia panorâmica: instrumento auxiliar no diagnóstico da osteoporose. Revista Brasileira de Reumatologia, 2008, vol. 48, n. 4, p. 226-233. http://dx.doi. org/10.1590/S0482-50042008000400006

MARKS, SC. and POPOFF, SN. Bone cell biology: the regulation of development, structure, and function in the skeleton. American Journal of Anatomy, 1988, vol. 183, n. 1, p. 2-44.

PARO, AH., AIZENSTEIN, ML., DELUCIA, R. and PLANETA, CS. Exposição repetida à cafeína aumenta a atividade locomotora induzida pelo fenproporex em ratos adolescentes e adultos. Revista Brasileira de Ciências Farmacêuticas, 2008, vol. 44, n. 3, p. 417 424.

PINTO, NAVD. Avaliação química e sensorial de diferentes padrões de bebida do café arábica cru e torrado. Lavras: Universidade Federal de Lavras, 2002. 92 p. [Tese de Doutorado em Ciência dos Alimentos].

RODRIGUES, IR. Composição química do café do Alto Vale do Jequitinhonba e comparação dos efeitos subcrônicos da cafeina e do café em ratos. Diamantina: Universidade Federal dos Vales do Jequitinhonha e Mucuri, 2012.97 p. [Dissertação de Mestrado].

RODRÍGUEZ-MARTÍNEZ, MA. and GARCÍA-COHEN, EC. Role of $\mathrm{Ca}^{2+}$ and vitamin $\mathrm{D}$ in the prevention and treatment of osteoporosis. Pharmacology and Therapeutics, 2002, vol. 93, n. 1, p. 37-49. http://dx.doi.org/10.1016/S0163-7258(02)00164-X

SADOCK, BJ. and SADOCK, VA. Manual de psiquiatria clínica. 5. ed. Porto Alegre: Artmed, 2012. p. 594.

SAKAMOTO, W., NISHIHIRA, J., FUJIE, K., IIZUKA, T., HANDA, H., OZAKI, M. and YUKAWA, S. Effect of coffee consumption on bone metabolism. Bone, 2001, vol. 28, n. 3, p. 332336. http://dx.doi.org/10.1016/S8756-3282(00)00444-0

SILVA, P. Farmacologia. 8. ed. Rio de Janeiro: Guanabara Koogan, 2010.

SOARES, EV., FAVARO, WJ., CAGNON, VHA., BERTRAN, CA. and CAMILLI, JA. Effects of alcohol and nicotine on the mechanical resistance of bone and bone neoformation around hydroxyapatite implants. Journal of Bone and Mineral Metabolism, 2010, vol. 28, n. 1, p. 101-107. PMid:19669082. http://dx.doi.org/10.1007/ s00774-009-0115-1

SOARES, EA., NAKAGASHI, WR., GARCIA, JAD. and CAMILLI, JA. Effect of hyperlipidemia on femoral biomechanics and morphology in low-density lipoprotein receptor gene knockout mice. Journal of Bone and Mineral Metabolism, 2012, vol. 30, p. 419-425. PMid:22246084. http://dx.doi.org/10.1007/s00774011-0345-x

SOUZA, MPG. Diagnóstico e tratamento da osteoporose. Revista Brasileira de Ortopedia, 2010, vol. 45, n. 3, p. 220-229.

SVENDSEN, P. and HAU, J. Handbook of laboratory animal science. Boca Raton: CRC Press, 1984. [vol. 1].

TSUANG, YH., SUN, JS., CHEN, LT., SUN, SC. and CHEN, SC. Direct effects of caffeine on osteoblastic cells metabolism: the possible causal effect of caffeine on the formation of osteoporosis. Journal of Orthopaedic Surgery and Research, 2006, vol. 1, p. 7. PMid:17150127 PMCid:PMC1636032. http://dx.doi. org/10.1186/1749-799X-1-7

TURNER, CH. and BURR, DB. Basic biomechanical measurements of bone: a tutorial. Bone, 1993, vol. 14, n. 4, p. 595-608. http:// dx.doi.org/10.1016/8756-3282(93)90081-K

Received: October 22, 2013 Accepted: April 21, 2014 